\title{
Using a participatory-based toolkit to build resilience and adaptive capacity to climate change impacts in rural India: A new paradigm shift for rural communities in the Himalaya
}

Lance Heath ${ }^{\mathrm{a}}$, Prakash Tiwari ${ }^{\mathrm{b}}$, Bedoshruiti Sadhukhan ${ }^{\mathrm{c}}$, Sunandan Tiwari ${ }^{\mathrm{d}}$, Bhagwati Joshi ${ }^{\mathrm{e}}$, Ailikun ${ }^{\mathrm{f}}$, Prem Sagar Chapagain ${ }^{\mathrm{g}}$, Tingbao Xu ${ }^{\mathrm{h}}$, Geraldine $\mathrm{Li}^{\mathrm{h}}$, and Jianzhong Yan ${ }^{\mathrm{i}}$

a Sustineo Pty Ltd., 1b/32 Thesiger Court, Canberra, ACT 260o, Australia

$b$ Kumaon University, Nainital-263 oo1, India

ICLEI - Local Governments for Sustainability South Asia C-3 Green Park Extension, New Delhi, India

d ICLEI World Secretariat, Kaiser-Friedrich-Strasse 7 D-53113 Bonn, Germany

e Government Post Graduate College, Rudrapur 263153, India

$f$ Chinese Academy of Sciences (CAS), No. 16 Lincui Road Chaoyang District, Beijing 100101, China

Tribhuvan University, Kirtipur, Nepal

$h$ The Australian National University, Canberra, o20o, Australia

Southwest University, Beibei District, Chongqing, China

Corresponding author.Email: lheath@grapevine.com.au.

\section{ABSTRACT}

The Himalaya-Tibetan Plateau, also known as the Water Tower of Asia, has the highest mountains and glaciers in the world. Meltwater from this huge reserve feeds some of Asia's major river basins. Changing monsoon patterns, more extreme weather events and continued melting of glaciers have long-term implications for the region's water, energy and food security. This project utilized the ICLEI/Asian Cities Climate Change Resilience Network (ACCCRN) toolkit, referred to as IAP, to assist local governments to assess their climate risks and vulnerabilities, and to make adaptive response plans accordingly. Although specifically designed for cities, the IAP Toolkit was applied to the rural watershed of Ramgad in Uttarakhand, India. Over 40 resilience interventions were developed for vulnerable communities in Ramgad. The results of this work revealed that adaptive capacity and resilience in this rural jurisdiction were much lower compared to those of urban settings. Rural regions typically have less resources available to measure threats, disruptions and impacts compared to their city counterparts. The application of the IAP to this rural enclave has shown that a new paradigm shift is needed for the refinement of decision support tools to measure climate impacts and to build resilience and adaptive capacity in rural Himalaya.

\section{HIGHLIGHTS}

» Five fragile systems were identified for the watershed of Ramgad

» Over 40 resilience interventions were developed and assessed for their feasibility and long-term impact

» Some of the intervention strategies are cost-effective and could be implemented immediately

» The sensitivity of the IAP Toolkit scoring system could be improved to truly reflect the rural environment

» Climate and hydrological data analysis could be improved by using the appropriate software

\section{KEYWORDS}

Adaptive Capacity, Climate change, Himalaya, IAP Toolkit, Resilience

DOI

https://doi.org/10.30852/sb.2018.292

\section{DATES}

Received: 15 December 2017 Published (online): 27 April 2018 Published (PDF): 14 November 2018 


\section{INTRODUCTION}

The Himalaya-Tibetan Plateau, also known as the Water Tower of Asia or the Third Pole, is home to the highest mountains and glaciers in the world. The meltwater from this huge reserve supports the wellbeing of some of the poorest people and most densely populated regions on the planet through the provision of water for drinking, irrigation and hydro-power generation (Heath et al., 2014). In addition, biomass-based subsistence agriculture is the main form of rural livelihood and food supply in the Himalaya (Tiwari \& Joshi, 2012a; Tiwari \& Joshi, 2012b).

The Himalayan region has seen an increase in the annual mean temperature and has borne the full brunt of climate change. An ever-increasing demand for the region's natural resources has exacerbated the impacts of climate change as evidenced by the severe water scarcity issues faced in the Midhills of Nepal (Chapagain et al., 2017). Among the numerous complex outcomes, we can expect to see the increasing consequences of climate change for river flows, groundwater recharge, food and energy security, migration, ecosystem services and human livelihood. These have inextricable implications for the many and varied rural communities that call the Himalayas home, and has emphasised the need to strengthen resilience and adaptive capacity for some of the World's most vulnerable people. Building resilience to future climatic disruptions calls for a broad framework centred on system resilience and adaptive capacity and transformative adaptive capacity.

From a policy perspective, mainstreaming adaptation into development and management strategies requires a proactive, holistic and systematic approach that does not regard adaptation measures as something distinct or excluded from other policies. Local ownership of the adaptive process is critical in ensuring adoption and buy-in and, ultimately, its sustainability and effectiveness (Nunn, 2009). Therefore, the role of participatory approaches in field based assessments to help communities derive the maximum benefit from the adaptation process is widely used and acknowledged (Fazey et al., 2010; Van Aalst et al., 2008). The role of Governments and other actors is also important in the adaptation process (Hay, 2009; IFRCS, 2007 ).

Significant advances in seasonal weather forecasting and climate modelling have been made over the last decade, leading to significant improvements in early warning systems and longer-term adaptation planning. This has also emphasized the importance of taking a proactive (anticipatory) rather than reactive management approach to addressing climate change impacts (Hay, 2011). To help communities and governments navigate these processes and prioritize their responses, several "off the shelf" climate change adaptation toolkits are available to help communities adapt to the long-term impacts of climate change.

This activity utilized the ICLEI/Asian Cities Climate Change Resilience Network (ACCCRN) toolkit, referred to as the ICLEI ACCCRN Process (or IAP) (ICLEI, 2014). The IAP uses a participatory based approach, or Shared Learning Dialogue (SLD), to identify these risks and vulnerabilities and to formulate adaptive response plans accordingly. Although the IAP Toolkit is specifically designed for cities, the methodology was applied to the rural watershed of Ramgad in Uttarakhand, India. This is the first rural jurisdiction in India to use the IAP Toolkit without any modification to the methodology. This research also investigates whether a city based toolkit is appropriate for a rural system.

\section{METHODOLOGY}

\subsection{Synopsis of ICLEI ACCRN Process (IAP)}

The methodological framework was developed by the International Council for Local Environmental Initiatives (ICLEI) under the Asian Cities Climate Change Resilience Network (ACCCRN) known as ICLEI ACCCRN Process (IAP) or IAP Toolkit. The IAP has a total of six phases containing a set of sixteen tools to enable local governments to evaluate the climate risks of various systems in the context of vulnerability, and to formulate a series of resilience interventions in response to the fragile systems identified. The six phases are:

Phase 1-Engagement: This first phase focuses on acquiring political support or "buy-in" from the relevant watershed authorities and community groups. It also allows for the formation of a Climate Core Team and Stakeholder Group.

Phase 2-Climate Research and Impact Assessment: This phase involves a Shared Learning Dialogue (SLD) with the Climate Core Team and the Stakeholder Group. This interaction aims to have a mutual learning and sharing of experiences. An assessment of past climate trends and future climate projections is undertaken using climate research data which is then validated through analysis of regional climate data as well as local perceptions from rural stakeholders.

Phase 3-Vulnerabilities Assessment: This phase identifies the key vulnerabilities of each fragile rural system. It determines the spatial vulnerability for each fragile system. It also identifies the vulnerable population and the potential supporting "Actors" for each system.

Phase 4-Resilience Strategy: The relevant resilience 
interventions for the watershed are then identified from the results obtained from the previous phases. Resilience interventions are then prioritized according to a set of resilience indicators, their feasibility and applicability to the watershed.

Phases 5 and 6-Implementation and Monitoring \& Review: Following the identification of potential resilience interventions for the watershed, project implementation plans are then prepared and options for financing these projects are then explored.

Four villages were selected for the baseline questionnaire; they represent diverse socio-economic parameters suitable for the application of the IAP procedure. These villages included Naikana, Bohrakote, Satbunga and Nathuakhan. A series of meetings and workshops were also organized in each of the 4 villages in the presence of a range of stakeholders including officials from local government departments, representatives from private sectors, civil society organizations, non-governmental organizations as well as village and forest panchayats.

The IAP Toolkit Workbook is available online free of charge at http://resiliencetools.org/node/101

\section{RESULTS AND DISCUSSION}

\subsection{Rural Profile}

\subsubsection{Location and watershed characteristics}

Ramgad watershed is situated in the Lesser Himalayan ranges in the district Nainital in the newly carved Himalayan State of Uttarakhand (Figure 1). The watershed is between $29^{\circ} 24^{\prime}$ to $29^{\circ} 29^{\prime} \mathrm{N}$ latitudes and $79^{\circ} 29^{\prime}$ to $79^{\circ} 39^{\prime} \mathrm{E}$ longitudes and encompasses a geographical area of nearly $75.8 \mathrm{~km} 2$ and is between 1025 and $2346 \mathrm{~m}$ in altitude. Ramgad is one of the principal tributaries of River Kosi and is characterized by several geological for-

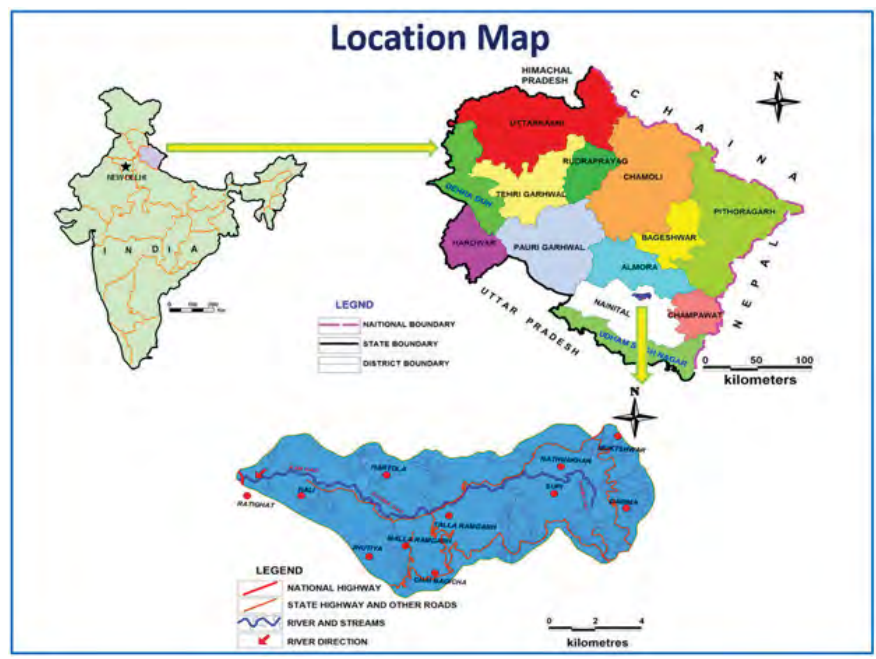

FIGURE 1. Ramgad Watershed situated in the lesser Himalayan ranges in the State of Uttarakhand. mations evidenced by rock displacement, slope failure and multi-cyclic river terraces.

\subsection{Past Hazards and Climatic Events}

The state of Uttarakhand is highly prone to natural disasters ranging from seasonal events such as forest fires, cloud bursts and flash flooding to unpredictable disasters such as earthquakes.

The Lesser Himalaya is vulnerable to landslides and the Ramgad region falls in Zone IV of the earthquake zoning map of India (Government of Uttarakhand, 2011). Zone IV is categorized as "severe to very severe". The Ramgad is also subject to landslides caused by excessive rainfall and runoff. During the summer months the watershed also experiences wild forest fires.

A timeline of hazards and extreme weather events was constructed based on historical records and perceptions. Figure 2 is the resulting timeline of events and their associated impacts.

\subsection{Climate Trends and Scenarios in the Ramgad Water- shed}

\subsubsection{Past climate trends}

An analysis of over 30 years of rainfall data from the Mukteshwar weather station has revealed an increase in rainfall since 1979 for the month of August, which represents the height of the monsoon season. The results suggest the monsoon season has increased in intensity, perhaps due to higher evaporation and greater inertia in the Asia Monsoon climate system.

However, during the drier months of December, January and February there has been a sharp decline in the amount of rainfall, which is consistent with the overall trend experienced across the Himalaya.

\subsubsection{Climate Change Projections and Climate Scenario Statements}

Climate change scenarios for the Nainital/Ramgad region were sourced from the CORDEX South Asia domain (50 km resolution). The climate projections were based on the Intergovernmental Panel on Climate Change (IPCC) A1B emission scenarios for the time period 2041 2060 compared to the baseline period (1981-2000).

Based on the climate change scenarios for the Ramgad region, there will be a decrease in the maximum temperature by $1^{\circ} \mathrm{C}$ during the summer monsoon season (June, July and August) and a decrease in the minimum temperature by $0.39^{\circ} \mathrm{C}$ for the same period. Temperatures during the winter months (December, January and February) are expected to increase. The maximum temperature will increase by $1.53^{\circ} \mathrm{C}$ in December, January and 


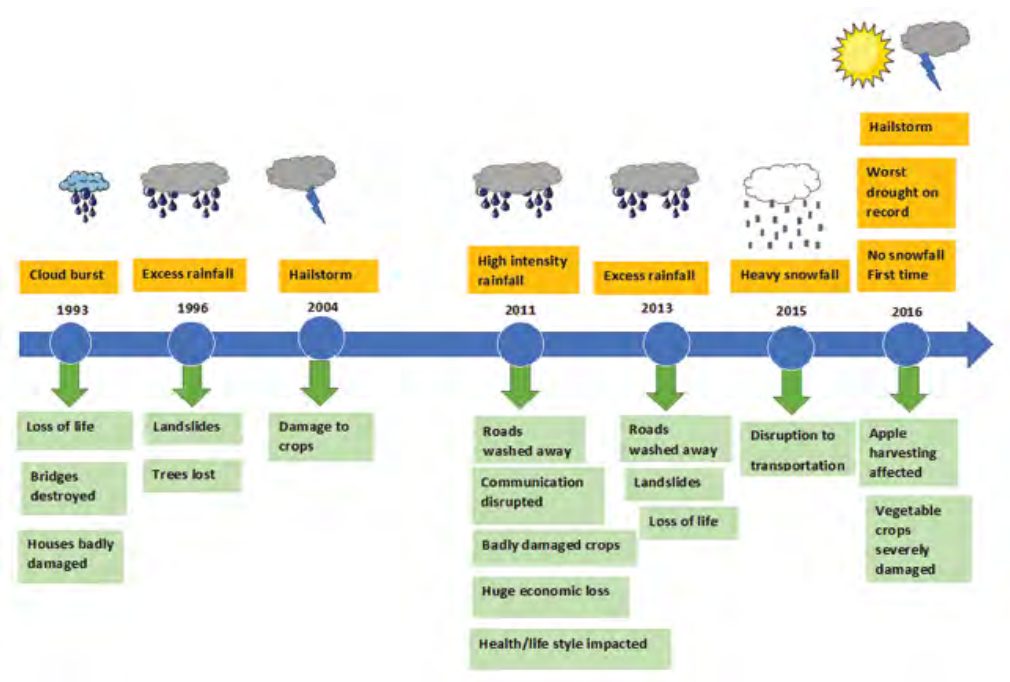

FIGURE 2. Timeline of hazards and extreme weather events and their impact on the community of Ramgad.

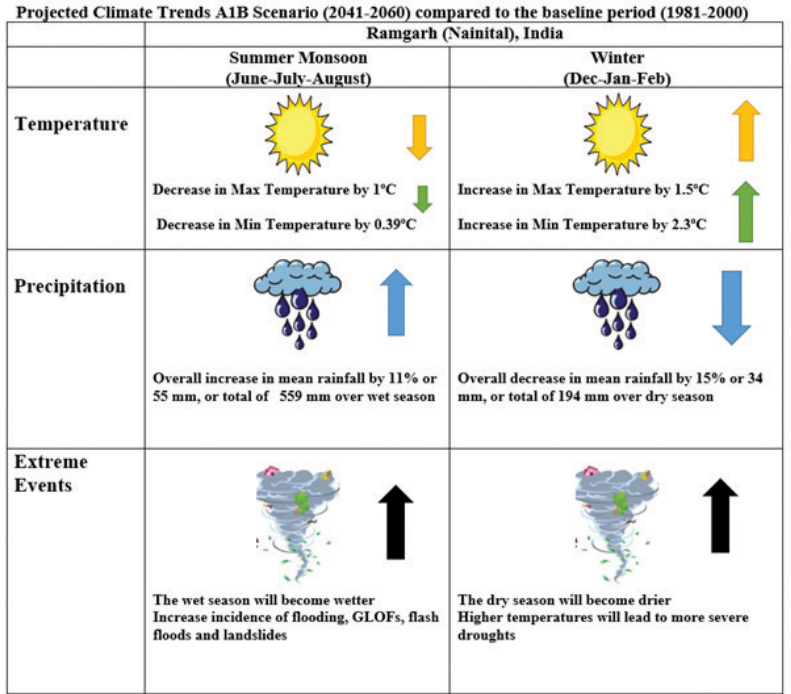

FIGURE 3. A diagrammatic representation of the projected climate change trend under the A1B Scenario (2041-2060) compared to the baseline period (1981-2000).

\begin{tabular}{|c|c|c|c|c|c|}
\hline \multirow{2}{*}{\begin{tabular}{l|} 
Rural system \\
Availability \\
and Supply \\
of Water for \\
Drinking and \\
Irrigation
\end{tabular}} & \multirow[b]{2}{*}{$\begin{array}{l}\text { Fragility statement } \\
\text { The system is fragile because the } \\
\text { water sources are sensitive to } \\
\text { small changes in the environment, } \\
\text { population growth and ecological } \\
\text { stress (i.e. emerging dominance } \\
\text { of pine trees). This in turn } \\
\text { impacts on drinking water supply, } \\
\text { human health and agricultural } \\
\text { production. }\end{array}$} & \multicolumn{4}{|c|}{ Climate fragility statement } \\
\hline & & $\begin{array}{l}\text { A decrease in } \\
\text { winter rainfall } \\
\text { and an increase } \\
\text { in temperature } \\
\text { during winter } \\
\text { will increase } \\
\text { the gap in the } \\
\text { demand and } \\
\text { supply of water. }\end{array}$ & $\begin{array}{l}\text { An increase in rainfall } \\
\text { and a decrease in summer } \\
\text { temperatures will lead to } \\
\text { high intensity rainfall and } \\
\text { a change in groundwater } \\
\text { dynamics (high intensity } \\
\text { rainfall may lead to } \\
\text { greater runoff and less } \\
\text { infiltration). }\end{array}$ & $\begin{array}{l}\text { Incidences of } \\
\text { high intensity } \\
\text { rainfall will } \\
\text { disrupt and } \\
\text { damage water } \\
\text { infrastructure } \\
\text { and } \\
\text { distribution } \\
\text { system. }\end{array}$ & $\begin{array}{l}\text { Water } \\
\text { sources may } \\
\text { become } \\
\text { dry due to } \\
\text { prolonged } \\
\text { droughts } \\
\text { affecting } \\
\text { water } \\
\text { availability. }\end{array}$ \\
\hline $\begin{array}{l}\text { Road } \\
\text { Connectivity }\end{array}$ & $\begin{array}{l}\text { Road infrastructure is fragile } \\
\text { due to the lack of resilience and } \\
\text { preparedness planning. Therefore, } \\
\text { road connectivity is adversely } \\
\text { affected if the road system is } \\
\text { disrupted thus impacting on the } \\
\text { rural economy and livelihoods. }\end{array}$ & \multicolumn{4}{|c|}{$\begin{array}{l}\text { Incidences of high intensity rainfall will disrupt roads and bridges, which will } \\
\text { in turn affect the rural economy, livelihood and community health. }\end{array}$} \\
\hline $\begin{array}{l}\text { Community } \\
\text { Human } \\
\text { Health and } \\
\text { Wellbeing }\end{array}$ & $\begin{array}{l}\text { Health facilities and human health } \\
\text { resources are unable to respond } \\
\text { to poor water sanitation, supply } \\
\text { and hygiene resulting from } \\
\text { unexpected shocks to the system. }\end{array}$ & \multicolumn{4}{|c|}{$\begin{array}{l}\text { Reduced availability of water will impact the rural food system, hygiene, } \\
\text { sanitation and community health. }\end{array}$} \\
\hline $\begin{array}{l}\text { Rural } \\
\text { Livelihoods } \\
\text { and } \\
\text { Economy }\end{array}$ & $\begin{array}{l}\text { On-going economic hardship, } \\
\text { droughts, extreme weather } \\
\text { events, and the lack of a reliable } \\
\text { water resource, have led to } \\
\text { an increase in out-migration, } \\
\text { food insecurity, and a loss of } \\
\text { purchasing power. }\end{array}$ & \multicolumn{4}{|c|}{$\begin{array}{l}\text { A decrease in rainfall, frequent droughts and increasing incidences of } \\
\text { high intensity rainfall will affect crop-rotation, agricultural productivity, } \\
\text { livelihood, tourism and the rural economy. }\end{array}$} \\
\hline $\begin{array}{l}\text { Forest } \\
\text { Resources }\end{array}$ & $\begin{array}{l}\text { The traditional forest based } \\
\text { subsistence farming constitutes } \\
\text { the main type of rural livelihood, } \\
\text { which is under threat from a } \\
\text { growing population and the } \\
\text { subsequent increase in the } \\
\text { demand for food, fodder, fuel } \\
\text { wood and other natural resources. }\end{array}$ & \multicolumn{4}{|c|}{$\begin{array}{l}\text { Increase in temperature and a decrease in rainfall will increase the incidence } \\
\text { of forest fire, loss of biodiversity, depletion of medicinal plants and a } \\
\text { reduction in the availability of fuel-wood and fodder. }\end{array}$} \\
\hline
\end{tabular}

TABLE 1. Climate Impacts on Fragile Systems (Fragility Statement \& Climate Fragility Statement) 


\begin{tabular}{|l|l|l|}
\hline Rural System & Climate Risks (Climate Fragility Statements) & Risk Status \\
\hline $\begin{array}{l}\text { Availability and Supply } \\
\text { of Water for Drinking } \\
\text { and Irrigation }\end{array}$ & $\begin{array}{l}\text { A decrease in winter rainfall and an increase in temperature during winter will increase } \\
\text { the gap in the demand and supply of water. }\end{array}$ & Extreme \\
\cline { 2 - 3 } & $\begin{array}{l}\text { An increase in rainfall and a decrease in summer temperatures will lead to high intensity } \\
\text { rainfall and a change in groundwater dynamics (high intensity rainfall may lead to } \\
\text { greater runoff and less infiltration). }\end{array}$ & High \\
\cline { 2 - 4 } & $\begin{array}{l}\text { Incidences of high intensity rainfall will disrupt and damage water infrastructure and } \\
\text { distribution system. }\end{array}$ & High \\
\cline { 2 - 4 } & Water sources may become dry due to prolonged droughts affecting water availability. & Extreme \\
\hline \multirow{2}{*}{ Road Connectivity } & $\begin{array}{l}\text { Incidences of high intensity rainfall will disrupt roads and bridges, which will in turn } \\
\text { affect the rural economy, livelihood and community health. }\end{array}$ & High \\
\hline $\begin{array}{l}\text { Community Human } \\
\text { Health and Wellbeing }\end{array}$ & $\begin{array}{l}\text { Reduced availability of water will impact the rural food system, hygiene, sanitation and } \\
\text { community health. }\end{array}$ & Extreme \\
\hline $\begin{array}{l}\text { Rural Livelihoods and } \\
\text { Economy }\end{array}$ & $\begin{array}{l}\text { A decrease in rainfall, frequent droughts and increasing incidences of high intensity } \\
\text { rainfall will affect crop-rotation, agricultural productivity, livelihood, tourism and the } \\
\text { rural economy. }\end{array}$ & Extreme \\
\hline \multirow{2}{*}{ Forest Resources } & $\begin{array}{l}\text { Increase in temperature and a decrease in rainfall will increase the incidence of forest } \\
\text { fire, loss of biodiversity, depletion of medicinal plants and a reduction in the availability } \\
\text { of fuel-wood and fodder. }\end{array}$ & Extreme \\
\hline
\end{tabular}

TABLE 2. Risk Assessment of Climate Fragility Statements.

February and the minimum temperature will increase by $2.26^{\circ} \mathrm{C}$ for the same period (i.e. winter months).

For precipitation, climate change projections indicate that there will be an overall increase in mean precipitation by as much as $10 \%$ during the summer monsoon period (June, July and August) but a decrease in rainfall during the winter months by as much as $15 \%$. Figure 3 is a synopsis of the expected change in climate and their corresponding climate change scenario statements. The climate risks likely to affect Ramgad are therefore:

Climate Risk 1: Increase in temperature overall and a decrease in rainfall overall.

Climate Risk 2: The wet season will become wetter with an increased incidence of extreme weather events resulting in more flash flooding and landslides.

Climate Risk 3: The dry season will become drier with more severe droughts.

A major problem is the lack of available climate data. Typically, mountainous regions of the Himalaya lack weather stations. Many areas are simply too difficult to access. This is the case for the Ramgad watershed in which there is only one weather station available at Mukteshwar. Therefore, the Ramgad watershed can be defined as a hydro-meteorological data deficit region.

\subsection{Climate Impact Assessment}

Based on a series of active discussions in the SLDs, five fragile systems were identified for the watershed of Ramgad that require immediate attention to help improve overall resilience to the impacts of climate change. These systems are: 1) Availability and Supply of Water for Drinking and Irrigation; 2) Road Connectivity; 3) Community Human Health and Wellbeing; 4) Rural
Livelihoods and Economy; and 5) Forest Resources.

The impacts from the climate scenarios (increased temperature, decreased precipitation and an increase in extreme events), were then superimposed on each fragile urban system to produce a series of climate fragility statements. The fragility statement and climate fragility statements for each rural system are summarised in Table 1.

\subsubsection{Rural Systems Analysis and Risk Assessment}

By using the participatory based risk assessment methodology outlined in the IAP Toolkit Workbook, the climate fragility statements were prioritized in order of their degree of risk that each expected climate impact poses for the identified fragile system(s) (Figure 4).

The participatory risk assessment exercise yielded alarming results for the all climate fragility statements (Table 2). For the rural system: Availability and Supply of Water for Drinking and Irrigation, two out of the four climate fragility statements yielded an extreme climate risk status. Likewise, the climate fragility statements for the rural systems: Community Human Health and Wellbeing, Rural Livelihoods and Economy and Forest Resources also yielded an extreme climate risk status. The remaining climate fragility statements all scored a high-risk status.

\subsection{Vulnerability Assessment}

The IPCC defines vulnerability as the degree to which a system is susceptible to, or unable to cope with, adverse effects of climate change (IPCC, 2001). Vulnerability is a function of a system's level of exposure, its sensitivity, and its adaptive capacity. A vulnerability assessment of 


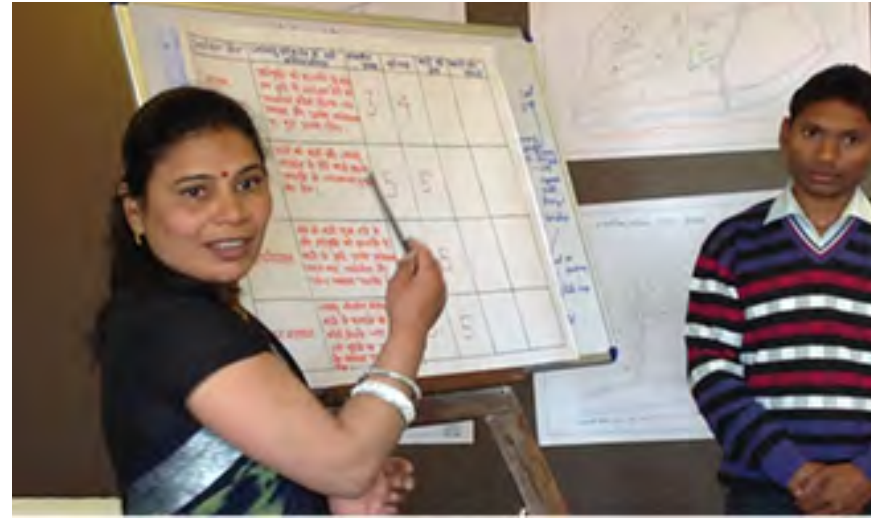

FIGURE 4. A risk assessment exercise was conducted in the Ramgad region with input from the Stakeholder Group.

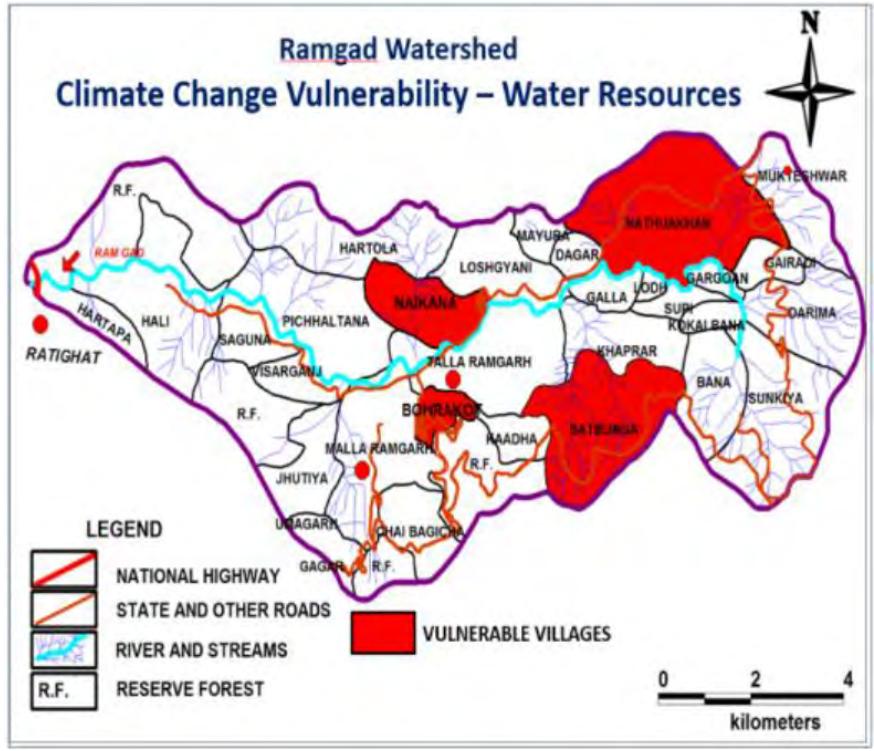

FIGURE 5. Vulnerable areas for the rural system Availability and Supply of Water for Drinking and Irrigation.

\begin{tabular}{|l}
\hline Climate Fragility Statements \\
\hline $\begin{array}{l}\text { 1) A decrease in winter rainfall and } \\
\text { an increase in temperature during } \\
\text { winter will increase the gap in the } \\
\text { demand and supply of water. }\end{array}$ \\
2) An increase in rainfall and a \\
decrease in summer temperatures \\
will lead to high intensity rainfall \\
and a change in groundwater \\
dynamics (high intensity rainfall \\
may lead to greater runoff and less \\
infiltration).
\end{tabular}

3) Incidences of high intensity rainfall will disrupt and damage water infrastructure and distribution system.

4) Water sources may become dry due to prolonged droughts affecting water availability.

\begin{tabular}{|c|c|c|c|c|c|c|}
\hline Villages & $\begin{array}{l}\text { People and } \\
\text { Institutions }\end{array}$ & $\begin{array}{l}\text { Capacity to } \\
\text { Organize \& } \\
\text { Respond }\end{array}$ & Resources & $\begin{array}{l}\text { Access to } \\
\text { Information }\end{array}$ & $\begin{array}{l}\text { Total } \\
\text { Score }\end{array}$ & $\begin{array}{l}\text { Adaptive } \\
\text { Capacity }\end{array}$ \\
\hline \multirow[t]{6}{*}{ Satbunga } & Women & 1 & 1 & 1 & 1 & Low \\
\hline & Gram Panchayat & 1 & 1 & 1 & 1 & Low \\
\hline & Forest Panchayat & 1 & 1 & 1 & 1 & Low \\
\hline & $\begin{array}{l}\text { Tourist } \\
\text { Enterprises }\end{array}$ & 1 & 2 & 1 & 2 & Low \\
\hline & Jal Sansthan & 1 & 2 & 1 & 2 & Low \\
\hline & NGOs & 2 & 2 & 1 & 4 & Low \\
\hline \multirow[t]{7}{*}{ Bohrakote } & Poor Households & 1 & 1 & 1 & 1 & Low \\
\hline & Women & 1 & 1 & 1 & 1 & Low \\
\hline & Gram Panchayat & 2 & 1 & 1 & 2 & Low \\
\hline & Forest Panchayat & 2 & 1 & 1 & 2 & Low \\
\hline & $\begin{array}{l}\text { Tourist } \\
\text { Enterprises }\end{array}$ & 1 & 2 & 1 & 2 & Low \\
\hline & Jal Sansthan & 1 & 2 & 1 & 2 & Low \\
\hline & NGOs & 2 & 2 & 1 & 4 & Low \\
\hline \multirow[t]{4}{*}{ Naikana } & Poor Households & 1 & 1 & 1 & 1 & Low \\
\hline & Women & 1 & 1 & 1 & 1 & Low \\
\hline & Gram Panchayat & 2 & 1 & 1 & 1 & Low \\
\hline & Jal Sansthan & 1 & 2 & 1 & 1 & Low \\
\hline \multirow[t]{6}{*}{ Nathuwakhan } & Poor Households & 1 & 1 & 1 & 1 & Low \\
\hline & Women & 1 & 1 & 1 & 1 & Low \\
\hline & Gram Panchayat & 1 & 1 & 1 & 1 & Low \\
\hline & Forest Panchayat & 2 & 1 & 1 & 1 & Low \\
\hline & $\begin{array}{l}\text { Tourist } \\
\text { Enterprises }\end{array}$ & 2 & 2 & 1 & 4 & Low \\
\hline & Jal Sansthan & 1 & 2 & 1 & 2 & Low \\
\hline
\end{tabular}

TABLE 3. Analysis of the adaptive capacities of local actors identified for the rural system Availability and Supply of Water for Drinking and Irrigation. 


\begin{tabular}{|c|c|c|c|c|c|c|}
\hline \multirow{2}{*}{$\begin{array}{l}\text { Fragile Rural } \\
\text { System }\end{array}$} & \multirow{2}{*}{$\begin{array}{l}\text { Vulnerable } \\
\text { Villages }\end{array}$} & \multicolumn{2}{|c|}{ Rural Actors } & \multicolumn{3}{|c|}{ Adaptive Capacity of the System } \\
\hline & & $\begin{array}{l}\text { Vulnerable } \\
\text { Communities }\end{array}$ & Actors & Low & Medium & High \\
\hline \multirow{10}{*}{$\begin{array}{l}\text { Availability and Supply of } \\
\text { Water for Drinking and } \\
\text { Irrigation } \\
\text { Road Connectivity } \\
\text { Community Human Health } \\
\text { and Wellbeing }\end{array}$} & \multirow{10}{*}{$\begin{array}{l}\text { Satbunga } \\
\text { Bohrakote } \\
\text { Naikana } \\
\text { Nathuakhan }\end{array}$} & \multirow{10}{*}{$\begin{array}{l}\text { Poor Households } \\
\text { Women } \\
\text { Tourist Enterprises } \\
\text { Vegetable Grower } \\
\text { Fruit Producers }\end{array}$} & $\begin{array}{l}\text { Block } \\
\text { Development } \\
\text { Office }\end{array}$ & $\begin{array}{l}\text { Economic } \\
\text { Technology }\end{array}$ & $\begin{array}{l}\text { Governance } \\
\text { Societal }\end{array}$ & - \\
\hline & & & Jal Sansthan & Economic & Technology & - \\
\hline & & & $\begin{array}{l}\text { Public Works } \\
\text { Department }\end{array}$ & $\begin{array}{l}\text { Governance } \\
\text { Societal } \\
\text { Ecosystem } \\
\text { Services }\end{array}$ & Economic & Technology \\
\hline & & & $\begin{array}{l}\text { Agriculture } \\
\text { Department }\end{array}$ & $\begin{array}{l}\text { Economic } \\
\text { Governance } \\
\text { Societal }\end{array}$ & $\begin{array}{l}\text { Technology } \\
\text { Ecosystem }\end{array}$ & - \\
\hline & & & $\begin{array}{l}\text { Forest } \\
\text { Department }\end{array}$ & Economic & $\begin{array}{l}\text { Technology } \\
\text { Governance } \\
\text { Societal }\end{array}$ & $\begin{array}{l}\text { Ecosystem } \\
\text { Services }\end{array}$ \\
\hline & & & $\begin{array}{l}\text { Horticulture } \\
\text { Department }\end{array}$ & Economic & $\begin{array}{l}\text { Technology } \\
\text { Governance } \\
\text { Societal }\end{array}$ & $\begin{array}{l}\text { Ecosystem } \\
\text { Services }\end{array}$ \\
\hline & & & $\begin{array}{l}\text { Irrigation } \\
\text { Department }\end{array}$ & $\begin{array}{l}\text { Economic } \\
\text { Ecosystem } \\
\text { Services }\end{array}$ & $\begin{array}{l}\text { Technology } \\
\text { Governance } \\
\text { Societal }\end{array}$ & - \\
\hline & & & $\begin{array}{l}\text { Gram } \\
\text { Panchayat }\end{array}$ & $\begin{array}{l}\text { Economic } \\
\text { Ecosystem } \\
\text { Services } \\
\text { Technology }\end{array}$ & $\begin{array}{l}\text { Societal } \\
\text { Governance }\end{array}$ & - \\
\hline & & & $\begin{array}{l}\text { Forest } \\
\text { Panchayat }\end{array}$ & $\begin{array}{l}\text { Economic } \\
\text { Technology }\end{array}$ & Societal & $\begin{array}{l}\text { Ecosystem } \\
\text { Services } \\
\text { Governance }\end{array}$ \\
\hline & & & NGOs & - & $\begin{array}{l}\text { Economic } \\
\text { Technology }\end{array}$ & $\begin{array}{l}\text { Ecosystem } \\
\text { Societal } \\
\text { Governance }\end{array}$ \\
\hline
\end{tabular}

TABLE 4. Adaptive Capacity of Rural Systems assessed against the five parameters of Economy, Technology, Governance, Societal and Ecosystem Services.

the Ramgad watershed was carried out and those villages identified as highly vulnerable, based on the IAP vulnerability scale, were mapped. The results of this assessment showed that the villages Satbunga, Bohrakote, Naikana and Nathuwakhan, surveyed as part of the IAP, exhibited a high level of vulnerability to climate change for all rural systems except for the rural system Forest Resources. The village of Satbunga was the only village that showed a high level of vulnerability to climate change for this system. Figure 5 shows the highly vulnerable areas for the rural system Availability and Supply of Water for Drinking and Irrigation.

\subsubsection{Actor Analysis}

An Actor Analysis involves the establishment of a structured list of individuals, government agencies and organizations with differing views, priorities and opinions. These individuals, organizations and agencies are referred to as "Actors". Their skills and capabilities to assist the most vulnerable during times of threat or disruption can vary significantly. The identification of "Actors" (i.e. different parties and individuals) and their capacity to organize and respond to threat or disruption was also undertaken. In the context of the IAP actor analysis, all actors received a "Low" score overall in terms of their adaptive capacity (Table 3). No Actor received a "Medium" or "High" score in terms of their adaptive capacity. In contrast, for the city of Nainital, four actors received a "High" score and five actors received a "Medium" score (Unpublished data).

Through the SLD workshops, participants discovered that the sensitivity relating to the IAP scoring system could be improved to truly reflect the rural environment. Therefore, the IAP scoring system may not be suitable for assessing the adaptive capacity of Actors to respond to shocks and disruptions. An alternative or more "sensitive" ranking scale is probably required to reflect a more realistic level of adaptive capacity for each Actor.

\subsubsection{Adaptive Capacity of Fragile Rural Systems}

There was a low adaptive capacity with respect to the "economic" parameter for nearly all potential sup- 
porting actors, suggesting a limited inherent economic ability to adapt to impacts (Table 4) (e.g. probably having no legal authority to raise funds and/or no strong tax base to call upon).

Ecosystem services also ranked "low" for the Public Works Department, Irrigation Department and Gram Pamchayat. On the other hand, the Forest Department and Horticulture Department, Forest Panchayat and NGOs had scored a "high" level of adaptive capacity for the parameter "ecosystems services". The Public Works Department also had a "high" level of adaptive capacity in terms of their technological knowledge and resources. However, this department and the Agricultural Department appeared to have limited governance structures in place to adapt to impacts, perhaps due to a lack of interagency collaboration or support from higher levels. Interestingly, the NGOs scored a "high" level of adaptive capacity for three out of the five parameters, namely ecosystem services, societal and governance.

\subsubsection{Gap Analysis}

The gap analysis revealed serious data deficiencies around stream discharge and water demand, and supply requirements. Information is also deficient in agriculture and food systems analysis. In addition, there has been little work done on determining the extent of biodiversity loss within the Ramgad watershed.

\subsection{RESILIENCE INTERVENTIONS}

A series of intervention strategies were developed for each rural system and these were prioritized according to their redundancy, flexibility, responsiveness, access to information and overall impact. Over 40 potential resilience interventions were identified across the five rural systems and these have been summarized in Table 5. Some of the intervention strategies are cost effective and could be implemented immediately. Greater awareness of water conservation, as well as the revival of some traditional water management strategies, were viewed as a way of ameliorating some of the negative impacts on the availability and supply of water for drinking and irrigation purposes. Some simple and cost-effective measures, such as the transportation of water by tankers and the development of water reuse strategies, could assist communities in the short-term. Programmes that focus on geological mapping and water quality monitoring to help reduce the incident of water-borne diseases could be implemented immediately. While there are conservation and protection measures in place for water supplies within the Ramgad watershed, the lack of water quality monitoring has made it difficult to assess the effectiveness of such measures. Based on the SLD, community groups have endorsed these potential resilience interventions as high priority.

Although there has been extensive research into the use of climate resilient varieties of seeds to maintain or increase food production and conserve water, there is a need to implement a long-term programme to improve food security and conserve water resources. Maintaining road connectivity was viewed by stakeholders as an important issue to prevent long-term isolation and economic loss through the inability to transport produce to markets and distribution centres. Local materials such as wood could be used to repair bridges damaged as result of extreme weather events and flash flooding. The installation of check dams (first order streams) to prevent excessive erosion, would also help to ameliorate some of the consequences (slope failures, landslides, debris and mud flow) resulting from intense rainfall events.

The institutionalization of sustainable forest management practices to enable forest panchayats to manage forests more sustainably was viewed as an important intervention strategy by the Stakeholder Group, but requires a more comprehensive programme that will integrate all disciplines (natural, economic and social aspects) into the one programme. Furthermore, there is also a need for the delineation and management of fire lines in forests to ensure a more sustainable forest fire management regime. The farming community viewed wild native animals as a major problem because of their tendency to consume food crops. A potential resilience intervention strategy would be to ensure an adequate food supply is available in forests to prevent animals from moving to farm land in search of food. Clearly, this would require a strong focus on maintaining and protecting ecosystem services. Unfortunately, ecosystem services were not highlighted as a rural system in this IAP but should form the basis of future work.

\subsubsection{Integration into Rural Plans}

Through extensive consultation with planning authorities and the Stakeholder Group, each resilience intervention developed as part of this IAP was then assessed to determine whether it belongs to an existing programme or whether it is an ongoing/upcoming or planned intervention. Around half of the intervention strategies were either planned or were on-going in their status.

\section{CONCLUSION}

The Ramgad watershed is experiencing dramatic social, economic and environmental pressures. The application of the IAP highlighted some key vulnerabilities to the impacts of climate change as well as some 


\begin{tabular}{|c|c|c|}
\hline Rural System & $\begin{array}{l}\text { Climate Risks } \\
\text { (Climate Fragility Statements) }\end{array}$ & Potential Resilience Interventions \\
\hline \multirow[t]{4}{*}{$\begin{array}{l}\text { Availability } \\
\text { and Supply } \\
\text { of Water for } \\
\text { Drinking and } \\
\text { Irrigation }\end{array}$} & $\begin{array}{l}\text { A decrease in winter rainfall and } \\
\text { an increase in temperature during } \\
\text { winter will increase the gap in the } \\
\text { demand and supply of water. }\end{array}$ & \multirow{4}{*}{$\begin{array}{l}\text { Tanker use } \\
\text { - Afforestation with broad leaf species } \\
\text { - Infiltration trenches } \\
\text { - Rainfall water harvesting } \\
\text { - Water reuse at the household level } \\
\text { - Revive traditional sources of water management } \\
\text { - Storing seasonal water in tanks } \\
\text { - Water resource management \& governance } \\
\text { Awareness regarding afforestation, water conservation \& reduction of } \\
\text { waste water }\end{array}$} \\
\hline & $\begin{array}{l}\text { An increase in rainfall and a } \\
\text { decrease in summer temperatures } \\
\text { will lead to high intensity rainfall } \\
\text { and a change in groundwater } \\
\text { dynamics (high intensity rainfall } \\
\text { may lead to greater runoff and less } \\
\text { infiltration). }\end{array}$ & \\
\hline & $\begin{array}{l}\text { Incidences of high intensity } \\
\text { rainfall will disrupt and damage } \\
\text { water infrastructure and } \\
\text { distribution system. }\end{array}$ & \\
\hline & $\begin{array}{l}\text { Water sources may become } \\
\text { dry due to prolonged droughts } \\
\text { affecting water availability. }\end{array}$ & \\
\hline $\begin{array}{l}\text { Road } \\
\text { Connectivity }\end{array}$ & $\begin{array}{l}\text { Incidences of high intensity } \\
\text { rainfall will disrupt roads and } \\
\text { bridges which will in turn affect } \\
\text { the rural economy, livelihood and } \\
\text { community health. }\end{array}$ & $\begin{array}{l}\text { - Geological mapping and survey to identify and reduce risks } \\
\text { - Adequate construction codes for roads \& the need to follow engineering } \\
\text { plans and guidelines \& retaining walls } \\
\text { - Construct good drainage systems like culverts } \\
\text { - Afforestation beside roads } \\
\text { - Use of oxen or horses for transporting goods temporarily } \\
\text { - Installation of check dams (first order streams) } \\
\text { - Temporary accessibility managed by local materials like wooden bridges, } \\
\text { wherever possible }\end{array}$ \\
\hline $\begin{array}{l}\text { Community } \\
\text { Human } \\
\text { Health and } \\
\text { Wellbeing }\end{array}$ & $\begin{array}{l}\text { Reduced availability of water } \\
\text { will impact the rural food } \\
\text { system, hygiene, sanitation and } \\
\text { community health. }\end{array}$ & $\begin{array}{l}\text { Awareness programmes on hygiene and sanitation for local people } \\
\text { - Availability of good medical facilities in community health centres } \\
\text { - Use of climate resilient varieties of seeds to maintain/increase food } \\
\text { production } \\
\text { - Revise Below Poverty Line (BPL) list to improve access to food security } \\
\text { Educational and socio-economic empowerment of women to improve } \\
\text { hygiene, sanitation, \& the health of the entire family } \\
\text { - Water quality checks of water sources like streams in villages } \\
\text { - Water quality checks of water sources like streams in villages } \\
\text { water, etc. } \\
\text { - Maintenance of water sources, conservation and protection of sources } \\
\text { from contamination }\end{array}$ \\
\hline $\begin{array}{l}\text { Rural } \\
\text { Livelihoods } \\
\text { and } \\
\text { Economy }\end{array}$ & $\begin{array}{l}\text { A decrease in rainfall, frequent } \\
\text { droughts and increasing } \\
\text { incidences of high intensity } \\
\text { rainfall will affect crop-rotation, } \\
\text { agricultural productivity, } \\
\text { livelihood, tourism and the rural } \\
\text { economy. }\end{array}$ & $\begin{array}{l}\text { - Use new varieties of seeds that use less water } \\
\text { - Reallocation of agricultural land use, revise cropping patterns } \\
\text { monkeys, etc.) } \\
\text { - Protection of forests to ensure livelihood protection of forest produce } \\
\text { users } \\
\text { - Develop a sustainable land use policy (Needs to be done at a State level) } \\
\text { - Diversification of livelihoods - bee keeping, fishery, poultry, etc., } \\
\text { alternative sources of employment to prevent out migration } \\
\text { - Create awareness to conserve local ecosystem - to maintain ecosystem } \\
\text { services } \\
\text { - Sustainability of agricultural business models, assessment and } \\
\text { improvement of producer consumer nexus, e.g. formation of cooperatives, } \\
\text { establishing market linkages, food processing units, etc. (Mukteshwar } \\
\text { Kisan Producer Company) }\end{array}$ \\
\hline $\begin{array}{l}\text { Forest } \\
\text { Resources }\end{array}$ & $\begin{array}{l}\text { Increase in temperature and a } \\
\text { decrease in rainfall will increase } \\
\text { the incidence of forest fire, loss } \\
\text { of biodiversity, depletion of } \\
\text { medicinal plants and a reduction } \\
\text { in the availability of fuel-wood } \\
\text { and fodder. }\end{array}$ & $\begin{array}{l}\text { - Institutionalization of sustainable forest management \& use practices - } \\
\text { Strengthen forest panchayats to manage forests sustainably using good } \\
\text { practices } \\
\text { - Sustainable use of forest resources } \\
\text { - Wild animals should be protected but consideration should be given to } \\
\text { protecting farmers' livelihoods. Efforts to cultivate food in forested areas } \\
\text { for wild animals to eat could be considered as a way of ameliorating the } \\
\text { consumption of food crops. } \\
\text { - Replace firewood with alternative energy sources such as solar \& wind } \\
\text { - Create awareness of medicinal plants to improve livelihoods and the } \\
\text { economy } \\
\text { - Delineation and management of fire lines in forests for forest fire } \\
\text { management }\end{array}$ \\
\hline
\end{tabular}

TABLE 5. IDENTIFICATION OF Potential Resilience Interventions for each rural system. 
practical adaptive measures that can be implemented to strengthen community resilience in light of the impending challenges that lie ahead.

The first time the IAP Toolkit was used in a rural context was in the jurisdiction of Panchkhal in Nepal. This region shares similar characteristics to those of the Ramgad Basin in India. On this basis, we believed that the IAP approach would also work in the Ramgad. In conclusion, the IAP Toolkit showed that in both jurisdictions and with minor modifications, it is possible to assess the risks and level of vulnerability to climate impacts even though the IAP was developed for use in urban environments.

Reflecting on the outcomes of the IAP for the Ramgad region, the workshop participants found that rural resilience scores were all "low" compared to those of urban environments such as Nainital. Understandably, rural areas typically have less resources available to measure threats and impacts in the rural system. This is also compounded by the physical distances between cities that have better infrastructure and resources at their disposal (i.e. better hospitals and equipment, human resources etc.) and rural environments that quite often lack basic amenities, infrastructure as well as the ability to mobilise human resources en masse. This area of research should be explored and tested in more detail in future IAP studies that examine the adaptive capacity of rural environments.

The IAP revealed several challenges facing the Ramgad watershed. Perhaps the most pressing problem revealed by the IAP gap analysis and vulnerability assessment was the lack of data on stream discharge and its associated impact on the supply of fresh drinking water. This finding highlighted the need for the implementation of improved water governance and management practices.

An equally important issue was the lack of reliable climate data for forecasting future climate and hydrological shocks. Reliable climate information is essential to the quantitative assessment of climate impacts in mountain regions and for improving regional resilience and adaptive capacity to such impacts. The Ramgad watershed can be classified as a hydro-meteorological data deficit region. With a deficiency in weather stations and available climate data, it is almost impossible to create a spatial representation of rainfall and temperature across the entire watershed. Software programs that use an elevation-dependent algorithm, such as ANUSPLIN (Hutchinson and $\mathrm{Xu}, 2013$ ), to create spatial representations of rainfall and temperature in mountainous regions should form the basis for further work in this area. The climate surface maps generated from these software packages can then be used with a high degree of confidence to model rainfall/runoff in agricultural catchments by using a suite of hydrological software. The results from this analysis can inform policymakers on a range of watershed management issues including the optimization of rainfall capture and storage and to predict the bioclimatic distribution of organisms in response to a changing climate, by using some popular and easy-using bioclimatic modelling packages such as ANUCLIM (Xu and Hutchinson, 2013).

A lack of information on how climate change is affecting the region and how to respond to it was found to be a major barrier to adaptation. The IAP revealed a major deficiency in the accessibility and flow of information to those most in need. The development of a Knowledge Management Framework can help improve the flow and accessibility of information to farmers, tourist operators, forest managers, community leaders and policymakers. This is achieved through the development of a Knowledge Management Platform to encourage the collection and sharing of critical information and knowledge at multiple levels. Therefore, efforts should be made to initiate planning for the establishment of Knowledge Management Framework Platform.

Lastly, ICLEI with support from the Rockefeller Foundation, has finalized the IAP for the City of Nainital, which is approximately $40 \mathrm{~km}$ from the Ramgad watershed in the state of Uttarakhand, India. Because of the proximity of these two IAP study regions, future work should identify and examine crucial climate change adaptation linkages between the urban and rural sectors, and could form the basis for a new research endeavour.

\section{ACKNOWLEDGEMENT}

We gratefully acknowledge our collaborator ICLEI for the use of the IAP and a special thanks to Bedoshruiti Sadhukhan and Sunandan Tiwari from ICLEI for their in-kind support with the workshop facilitation and for conducting the IAP exercises with the Stakeholder Group. A special thanks to Professor PC Tiwari and his team of researchers and students for coordinating the field work and surveys. Lastly, we would like to thank APN and the APN Secretariat for their patience and support.

\section{REFERENCES}

Chapagain, P.S., Ghimire, ML., \& Shrestha, S. (2017) Status of Natural Springs in the Melamchi Region of the Nepal Himalayas in the Context of Climate Change. Environment, Development and Sustainability. https://doi.org/10.1007/s10668-017-0036-4.

Hay, J.E. (2011) Discussion Paper Pacific: Pacific Adaptation to Climate Change: Past Approaches and Considerations for the Future. Department of Climate 
Change and Energy Efficiency publication. Commonwealth of Australia 2012: ISBN 978-1-925006-02-5

Hay, J.E. (2009) Institutional and Policy Analysis of Disaster Risk Reduction and Climate Change Adaptation in Pacific Island Countries. Report prepared for the United Nations International System for Disaster Reduction and the United Nations Development Programme, Suva, Fiji.

Heath, L., Salinger, M.J., Falkland, T., Hansen, J., Jiang, K., Kameyama, Y., Kishi, M., Lebel, L., Meinke, M., Morton, K., Nikitina, E., Shukla, P.R \& White, I. (2014) Climate and Security in Asia and the Pacific (Food, Water and Energy) in Michael J. Manton and Linda Anne Stevenson (ed.). Climate in Asia and the Pacific: Security, Society and Sustainability, Springer, Dordrecht, Heidelberg, New York, London, pp. 129198. DOI: https://dx.doi.org/10.1007/978-94-0077338-7_4

Hutchinson, M.F. and Xu, T. (2013). ANUSPLIN Version 4.4. Fenner School of Environment and Society, Australian National University, Australia. http://fennerschool.anu.edu. au/research/software-datasets/ anusplin.

IPCC. (2001) Climatic changes 2001: Intergovernmental Panel on Climate Change. The scientific basis, Technical summary from Working Group I, IPCC, Geneva.

Tiwari P. C and Joshi B. (2012a) Environmental changes and sustainable development of water resources in the Himalayan headwaters of India, International Journal of Water Resource Management, 26 (4), pp. 883-907, https://link.springer.com/article/10.1007/ s11269-011-9825-y

Tiwari P. C and Joshi, B. (2012b), Natural and socio-economic factors affecting food security in the Himalayas, Journal of Food Security, 4 (2), pp. 195-207, DOI 10.1007/s12571-012-0178-z.

Fazey, I., Kesby, M., Evely, A., Latham, I., Wagatora D., Hagasua, J-E., Reed, M., and Christie, M. (2010) A three-tiered approach to participatory vulnerability assessment in the Solomon Islands, Global Environmental Change, 20, 713-728.

Government of Uttarakhand. (2011) Slope Instability and Geo-environmental Issues of the Area around Nainital, Disaster Management and Mitigation Centre, Government of Uttarakhand, Report, Disaster Management and Mitigation Centre, Government of Uttarakhand, Dehradun.

IFRCS. (2007) Preparing for a Changing Climate: Case Study. Pacific Delegation, Pacific Red Cross Societies, International Federation of Red Cross and Red Crescent Societies, Suva, Fiji, 4pp.

ICLEI. (2014) ICLEI South Asia First Edition, December 2014. ICLEI - Local Governments for Sustainability,
South Asia.

Nunn, P.D. (2009). Responding to the challenges of climate change in the Pacific Islands: management and technological imperatives. Climate Research, 40, 211-231.

Van Aalst, M.K., Cannon, T and Burton, I. (2008) Community level adaptation to climate change: The potential role of participatory community risk assessment. Global Environmental Change, 18, 165179.

Xu, T. and Hutchinson, M.F. (2013). New developments and applications in the ANUCLIM spatial climatic and bioclimatic modelling package. Environmental Modelling and Software, 40, 267-279 [40, 52]. 